\title{
POPULATION STRUCTURE, DISTRIBUTION AND ABUNDANCE PATTERNS OF THE PATAGONIAN SMOOTHHOUND MUSTELUS SCHMITTI SPRINGER, 1939 \\ (CHONDRICHTHYES, ELASMOBRANCHII, TRIAKIDAE) IN THE RIO DE LA PLATA AND INNER CONTINENTAL SHELF, SW ATLANTIC OCEAN (34³0'-39³0'S)
}

\author{
María Cristina Oddone ${ }^{1,2 *}$, Laura Paesch ${ }^{2}$, Walter Norbis ${ }^{2} \&$ Gonzalo Velasco $^{1}$ \\ ${ }^{1}$ Universidade Estadual Paulista, Instituto de Biociências \\ Departamento de Ecologia \\ (Caixa Postal 199, 13506-900 Rio Claro, SP, Brasil)
}

${ }^{2}$ Dirección Nacional de Recursos Acuáticos (DINARA), Departamento de Biología Pesquera (Constituyente 1497, C.P: 11200-P.O. Box 1612, Montevideo, Uruguay)

*mcoddone@rc.unesp.br

\section{A B S T R A C T}

A total number of 4824 Mustelus schmitti was sampled. Females ranged from 25 to $93 \mathrm{~cm}$ in spring and from 28 to $90 \mathrm{~cm}$ in summer. Males ranged from 34 to 82 and from 28 to $77 \mathrm{~cm}$, respectively. Length composition of the population showed significant differences between spring and summer being females larger than males. Total length distribution did not show significant differences between cruises. Males density varied significantly between cruises while for the females no significant variation was observed. In the spring cruise, both sexes occurred at depths lower than 50 $\mathrm{m}$. Females occurred in the whole area with adult occurrence only above $35^{\circ} 30^{\prime} \mathrm{S}$. Mature males occurred throughout the area, immature males occurring in two trawls in Samborombón Bay. The summer cruise showed a discontinuous distribution of the species along the study area resulting in spatial segregation in two groups with immature females predominating in both of them.

\section{R ESUMO}

Um total de 4824 Mustelus schmitti foi amostrado. As fêmeas apresentaram comprimento total de 25$93 \mathrm{~cm}$ na primavera e $28-90 \mathrm{~cm}$ no verão enquanto os machos apresentaram $34-82$ e de $28-77 \mathrm{~cm}$, respectivamente. A composição de comprimentos da população mostrou diferenças significativas entre primavera e verão sendo as fêmeas maiores do que os machos. A distribuição de comprimento total não variou significativamente entre cruzeiros. A densidade variou significativamente entre cruzeiros nos machos sendo que a variação não foi expressiva nas fêmeas. No cruzeiro da primavera, ambos os sexos ocorreram em profundidades menores do que $50 \mathrm{~m}$, as fêmeas ocorrendo em toda a área de estudo, as adultas somente acima da latitude $35^{\circ} 30^{\prime} \mathrm{S}$. Os machos adultos foram observados em toda a área sendo que os imaturos somente em dois arrastos na Bahia de Samborombón. O cruzeiro de verão mostrou uma distribuição descontínua da espécie ao longo da área de estudo, resultando na segregação espacial em dois grupos, com predominância de fêmeas imaturas em ambos.

Descriptors: Mustelus schmitti, Triakidae, Population structure, Migration, Rio de la Plata, South western Atlantic, Sexual segregation.

Descritores: Mustelus schmitti, Triakidae, Estrutura populacional, Migração, Rio da Prata, Atlântico Sul-Ocidental, Segregação por sexos.

\section{INTRODUCTION}

The Mustelus (Triakidae) genus is composed of small and medium size shark species that inhabit demersal continental shelf areas. It is a diverse genus with 22 described species (Compagno, 1999 apud Carrier et al., 2004) distributed circumglobally in most temperate seas, many of them with limited distributions (Musick et al., 2004). Mustelus species are difficult to identify because of the partial overlap of many of the morphological, morphometric and meristic characters used to separate them and, as a consequence, an increasing number of "regional forms" have been recently discovered (Stevens, 2004).
Mustelus schmitti Springer, 1939 is a coastal, benthopelagic species, occurring from Patagonia in Argentina $\left(47^{\circ} \mathrm{S}\right)$ to Rio de Janeiro in Brazil $\left(22^{\circ} \mathrm{S}\right)$ (Figueiredo, 1977; Meneses \& Paesch, 1999; Cousseau \& Perrotta, 2000; Musick et al., 2004). In Southern Brazil, Uruguayan and Argentinean waters, this species is found from depths of $15 \mathrm{~m}$ up to $140 \mathrm{~m}$ (Vooren, 1997; Cousseau \& Perrota, 2000; Oddone et al., 2005). Two nursery areas have been detected in the coast of Buenos Aires Province; the first to the south of the Samborombóm Bay (36 $06^{\circ}$ 'S, $\left.57^{\circ} 00^{\prime} \mathrm{W}\right)$ and the second one in El Rincón (40 $\left.00^{\prime} \mathrm{S}, 62^{\circ} 00^{\prime} \mathrm{W}\right)$ (Cousseau \& Perrota, 2000). Mustelus schmitti is found in Uruguayan and Argentinean waters during 
summer and in south Brazilian shelf during winter (Vooren, 1997) where the species is commonly fished with bottom trawl gears from coastal areas up to 120 $\mathrm{m}$ (Figueiredo, 1997). This species has been intensely caught by the Argentinean coastal fleet because of its abundance (Cousseau, 1986). Due to its migratory behaviour, M. schmitti is caught by different fleets, which could be affecting different parts of the stock during its life cycle.

Shark populations are declining very rapidly, not only as a result of directed fisheries but also as bycatch in many other fisheries (Baum et al., 2003). Further knowledge is needed on the specific habitat requirements of coastal species and whether these habitats can continue to contribute to the reproduction of the species despite the human impact on the environment (Carrier et al., 2004).

Therefore, more biologically-integrated studies are necessary to guide the appropriate and effective management of $M$. schmitti in the Argentinean-Uruguayan Common Fishing Zone (Oddone et al., 2005).

Smoothhound males attain maturity at $59 \mathrm{~cm}$ and females at $72 \mathrm{~cm}$ of total length, with litter size varying from 1 to 10 and size-at-birth of $26 \mathrm{~cm}$ of total length (Oddone et al., 2005). Low annual fecundity as well as reproductive patterns (one year interval between litters) are a matter of concern for an endemic species like $M$. schmitti subjected to high fishing mortality (Oddone et al., 2005). Oddone et al., (op. cit.) analyzed the population structure of M. schmitti in the Rio de la Plata oceanic front in offshore areas (51 to $134 \mathrm{~m}$ depth). In the present work, the population structure of $M$. schmitti in inshore areas is analyzed during spring (1994 yr) and summer (1995 yr) with special attention to composition of the catches by sex, body length and spatial distribution of the maturity stages.

\section{Material and Methods}

Data Collection and Sampling Procedures

Data on the population structure and spatial distribution of Mustelus schmitti were obtained during two research cruises carried out in spring 1994 and summer 1995 on board the RV Aldebarán (operated by DINARA, Uruguay), designed for the assessment of demersal fisheries resources in the ArgentineanUruguayan Common Fishing Zone (AUCFZ) (Fig. 1; Table 1), at depths up to $60 \mathrm{~m}$ At each sampling location, a 30 min trawl haul was conducted at a towing speed of approximately 3 knots during daylight. A high-opening "Engel" type net of $80 \mathrm{~mm}$ (stretched mesh) codend was used. Sampling procedures and data processing followed Ehrhardt et al. (1977). Bottom water temperature $\left({ }^{\circ} \mathrm{C}\right)$ and salinity (psu $=$ practical salinity units) were recorded at each fishing station using conductivity-temperature-depth (CTD) profiler (Seabird 19). Fresh, randomly selected specimens of $M$. schmitti were sampled on board immediately after each trawling station. Sex and total length (TL) to the nearest $\mathrm{cm}$ below were recorded, sensu Compagno (1984).

\section{Data Analyses}

Density by sex (number of specimens by square $\mathrm{nm}$ ) was calculated using hauls where the species occurred. Differences between sexes for median density was carried out using Mann-Whitney (MW) non parametric test (Sokal \& Rohlf, 1998) When a subsample of individuals was obtained, data on TL by sexes for each single trawling station were expanded to the total catch data to obtain the TL's relative frequency by sexes (Table 1).

As TL data were non-normal and nonhomogeneous, then the differences between TL composition and median TL by sex from data of each cruise and between cruises for females and males were tested using M-W test (Sokal \& Rohlf, 1998).

Using $\chi^{2}$ test (Sokal \& Rohlf, 1998) we analyzed whether the proportion of males/females and immature/mature of patagonian smoothhound by trawl station were equal. Significance level used in the tests was 0.05 . According to the results obtained, the spatial distribution and abundance (density, individuals/square $\mathrm{nm}$ ) of females/males and immature/mature sharks by sex were plotted. Classification of the individuals as immature/mature was done according to criteria proposed by Oddone et al. (2005).

\section{Results}

Size Composition of the Population

A total number of 4824 M. schmitti (2582 males and 2242 females) was sampled. Female and male TL ranges and statistics are presented in Table 1. Females ranged from 25 to $93 \mathrm{~cm}$ in spring and from 28 to $90 \mathrm{~cm}$ in summer. Males ranged from 34 to 82 and from 28 to $77 \mathrm{~cm}$, respectively. Total length composition of the population showed significant differences between spring and summer $(P<0.05$, Table 1) with females larger than males. The relative frequency of TL by sex for both seasons is presented in Figures 2A; 2B. Total length distribution did not show significant differences $(\mathrm{U}=3.147 ; \mathrm{p}<0.05)$ between cruises. Regarding males, comparisons were significantly different between cruises $U=177.14$, $\mathrm{p}<0.05$ ) with higher median TL in summer (Table 1 , Fig. 2B). 


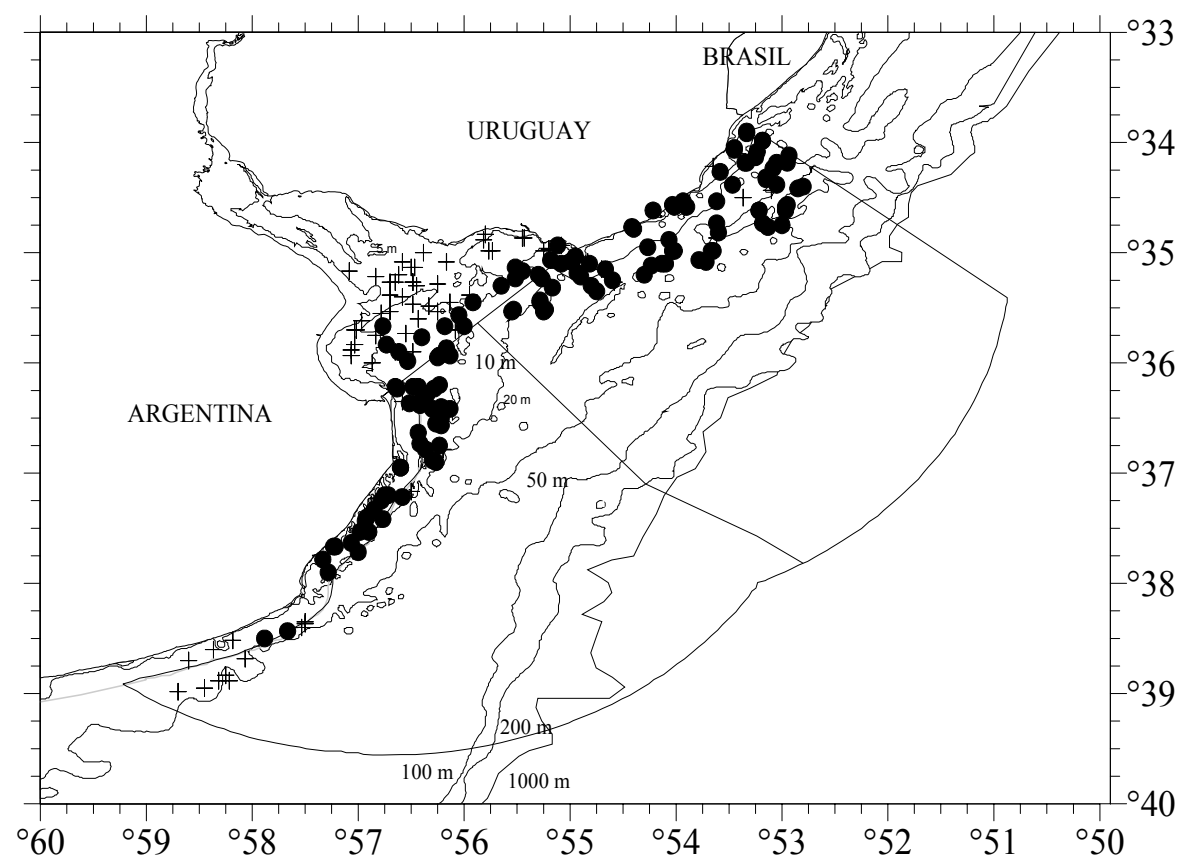

Fig. 1. Map of the study area, The Argentinean-Uruguayan Common Fishing Zone (AUCFZ), where the cruises were carried out. $(+)$ each fishing station; $(\bullet)$ stations where Mustelus schmitti occurred.

Table 1. Number of trawl stations (trawl), latitude, depth (range), temperature and salinity followed by latitude, depth, temperature and salinity for the trawls with occurrence of Mustelus schmitti, number (n), percentage (\%) and statistics for males and females, and number (n) and percentage (\%) of immature (I) and mature (M) specimens by sex and cruise. Statistics are mean, standard deviation (SD), median and total length $(\mathrm{cm})$ range. MW $(\mathrm{U})$ is the Mann Whytney value and $P$ the probability; for each cruise.

\begin{tabular}{|c|c|c|}
\hline & \multicolumn{2}{|c|}{ CRUISE } \\
\hline & Spring 1994 & Summer 1995 \\
\hline Date & November 4-November 24 & February 26-March 16 \\
\hline Trawl & 100 & 98 \\
\hline Latitude & $33^{\circ} 54^{\prime}-38^{\circ} 59^{\prime}$ & $33^{\circ} 55^{\prime}-38^{\circ} 24^{\prime}$ \\
\hline Depth & $3-58$ & $3.5-60$ \\
\hline Temperature* & $10.94-21.8$ & - \\
\hline Latitude* & $33^{\circ} 59^{\prime}-37^{\circ} 43^{\prime}$ & $33^{\circ} 55^{\prime}-37^{\circ} 47^{\prime}$ \\
\hline Depth* & $9-32$ & $6-52$ \\
\hline n & 2101 & 481 \\
\hline$\%$ ठ & 60 & 36 \\
\hline Mean $\delta$ & 63,59 & 64,74 \\
\hline SD ${ }^{\lambda}$ & 10,85 & 10,14 \\
\hline Median $\hat{o}$ & 65 & 66 \\
\hline Range $\delta$ & $25-93$ & $28-90$ \\
\hline $\mathbf{n}+$ & 1391 & 851 \\
\hline$\%$ 우 & 40 & 64 \\
\hline Mean 우 & 62,21 & 56,30 \\
\hline SD ${ }^{+}$ & 8,33 & 8,68 \\
\hline Median +9 & 63 & 58 \\
\hline Range ${ }^{\top}$ & $34-82$ & $28-77$ \\
\hline MW (U) & 828172 & 100041 \\
\hline$P$ & 0,000 & 0,000 \\
\hline
\end{tabular}




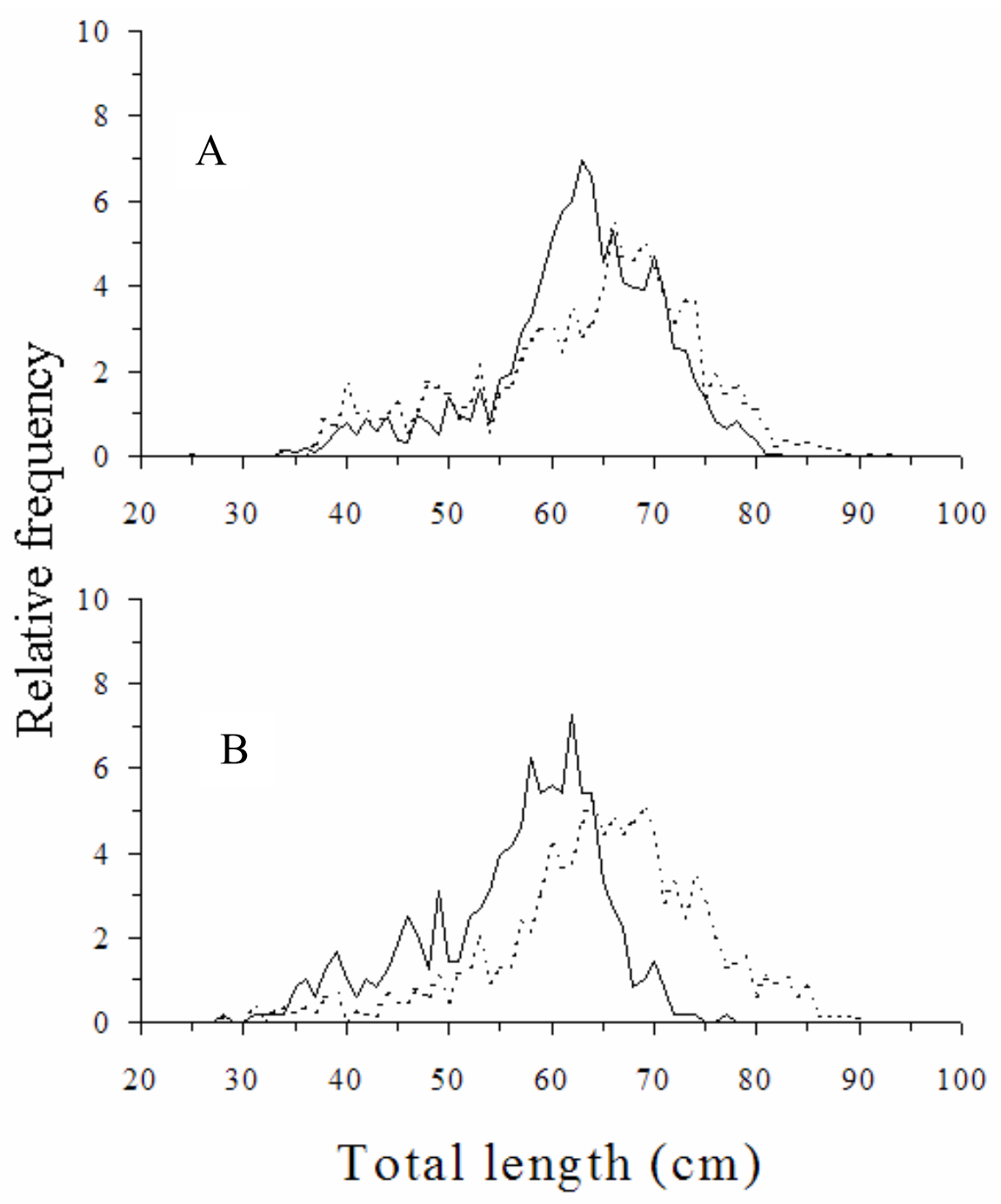

Fig. 2. Population structure Mustelus schmitti represented by the relative frequency of total length (cm) by sex in (A) the 1994 spring cruise and (B) the 1995 summer cruise (Males: continuous line; females: dotted line).

\section{Seasonal Distribution and Abundance}

Density varied significantly between cruises for males $(\mathrm{MW}=177.14 ; \mathrm{p}<0.05)$, while for females no remarkable variation was observed $(\mathrm{MW}=3.15$; $\mathrm{p}>0.05$ ) (Fig. 3). For the spring cruise both sexes occurred at depths lower than $50 \mathrm{~m}$ in the whole area. Females occurred in the whole area with adult (mature) occurrence only above $35^{\circ} 30^{\prime} \mathrm{S}$. Mature males occurred throughout the area and immature ones occurred in two trawls in Samborombón Bay (Figs $4 \mathrm{~A} ; 4 \mathrm{~B})$. The summer cruise showed a discontinuous 
distribution of the species along the study area resulting in spatial segregation in two groups with immature females predominating in both of them. Mature females occurred only in the northern group above 35³0'S (Fig. 5A). Mature males largely predominated in both groups, excepting one trawl when immature individuals were dominant (Fig. 5B). Relative frequency of TL by sex for both groups is presented in Figure 6. For both sexes, comparisons between length groups were significant $(U=20001.5$, $P<0.05 ; \mathrm{U}=49612, \mathrm{p}<0.05$, respectively) with higher median length in the northern group (Table 2). Females predominated $\left(\chi^{2}=200.6 ; \mathrm{p}<0.05\right)$ in the northern group while the same proportion of sexes $\left(\chi^{2}\right.$ $=0.328 ; \mathrm{p}>0.05)$ was found in the southern group.
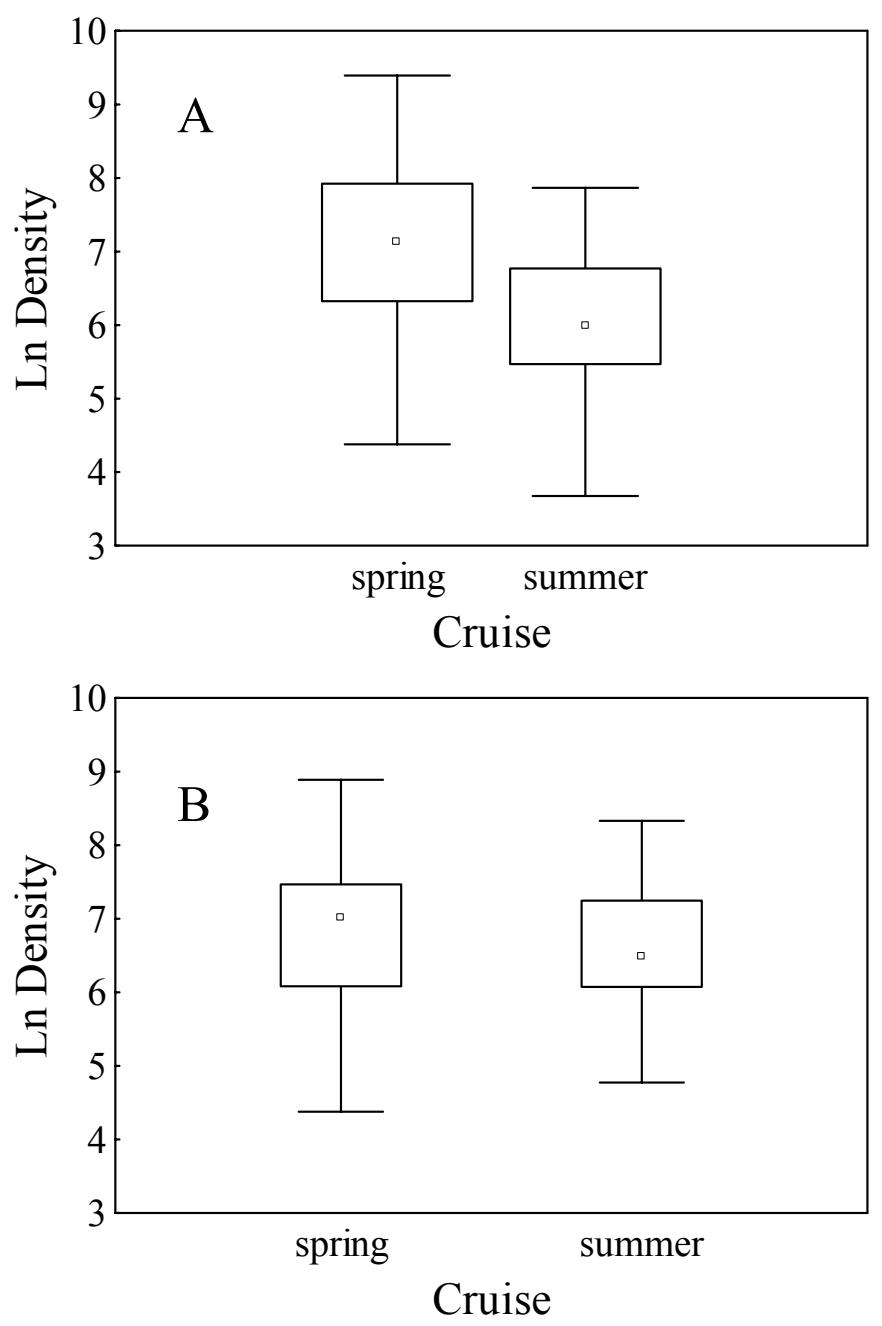

Fig. 3. Box-plot of density (number of individuals by square nautical mile) for males (A) and females (B) of Mustelus schmitti by cruise. Each single box represents the 25-75 percent quartiles; the median is shown with a square inside the box; minimal and maximal values are shown with horizontal lines. 

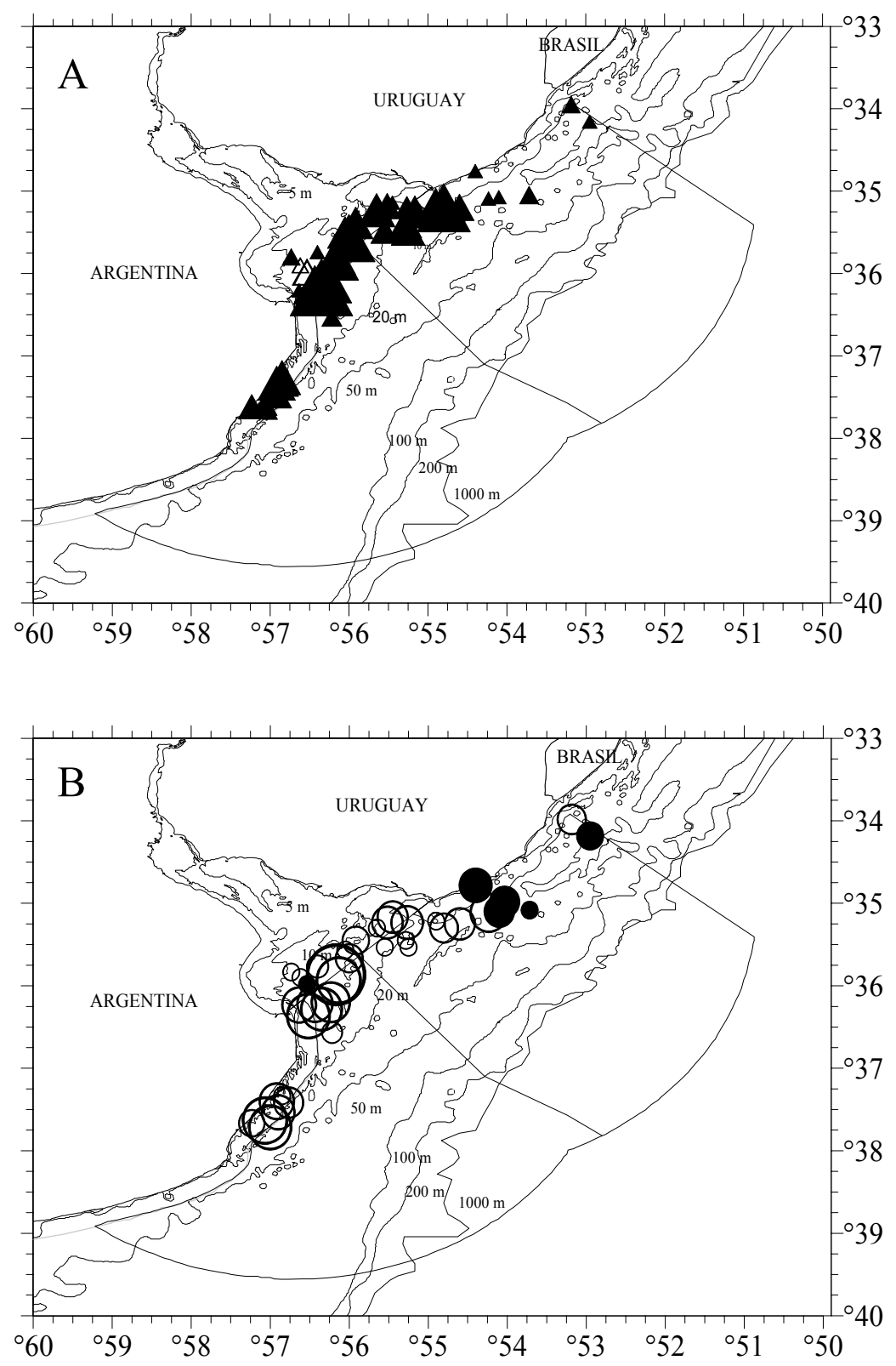

Fig. 4. Distribution and density of males ( $\mathbf{\Delta}$ ) (A) and females (०) (B) of Mustelus schmitti in the Argentinean-Uruguayan Common Fishing Zone for spring inshore cruise Immature and mature specimens are represented by empty and full symbols respectively. Symbol sizes correspond with densities of up to $\circ 500$, up to 3000 and more that 3000 specimens per square nautical miles. 


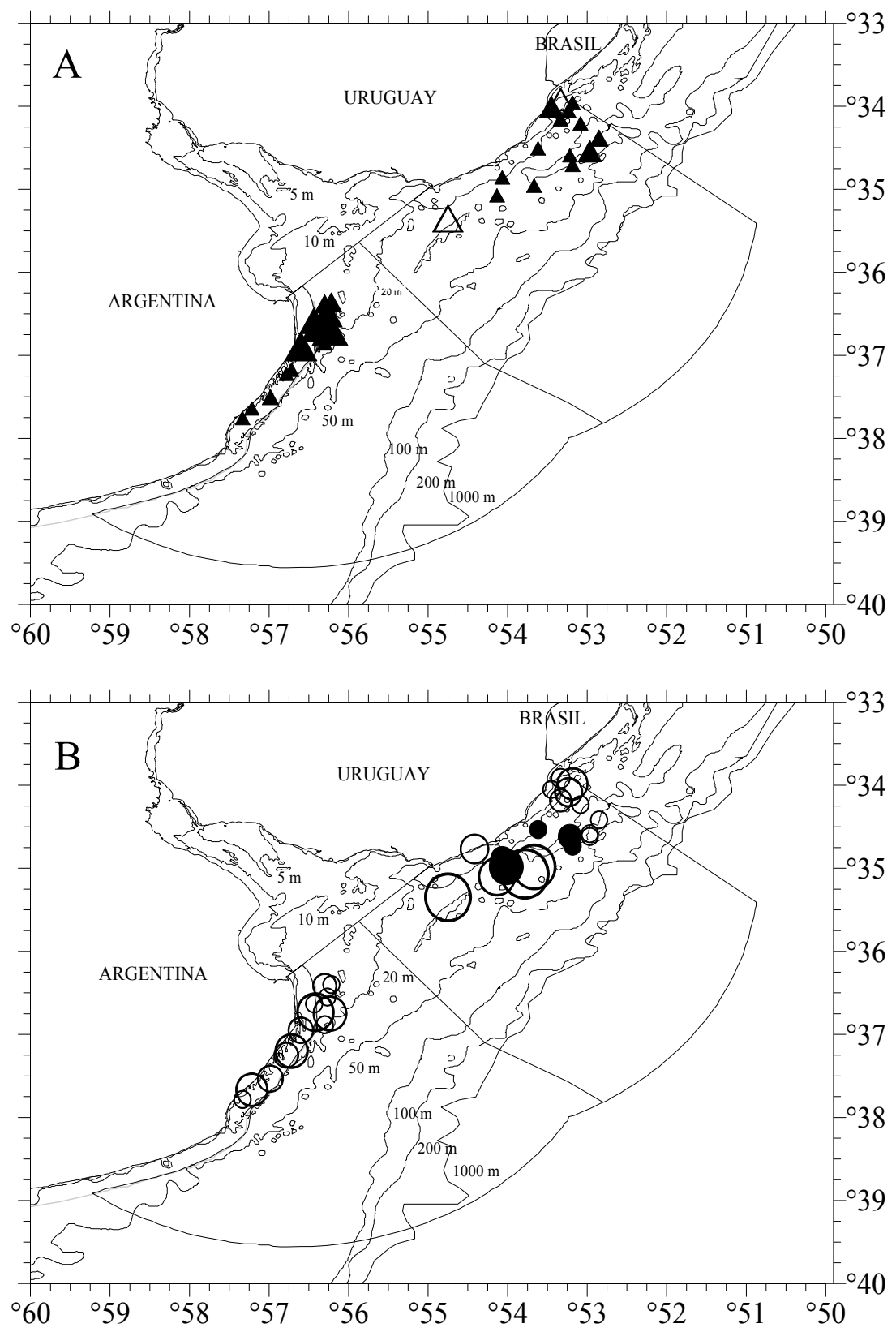

Fig. 5. Distribution and density of males (A) (A) and females (०) (B) of Mustelus schmitti in the Argentinean-Uruguayan Common Fishing Zone for summer inshore cruise. Immature and mature specimens are represented by empty and full symbols respectively. Symbol sizes correspond with densities of up to 500, up to 3000 and more that 3000 specimens per square nautical miles. 


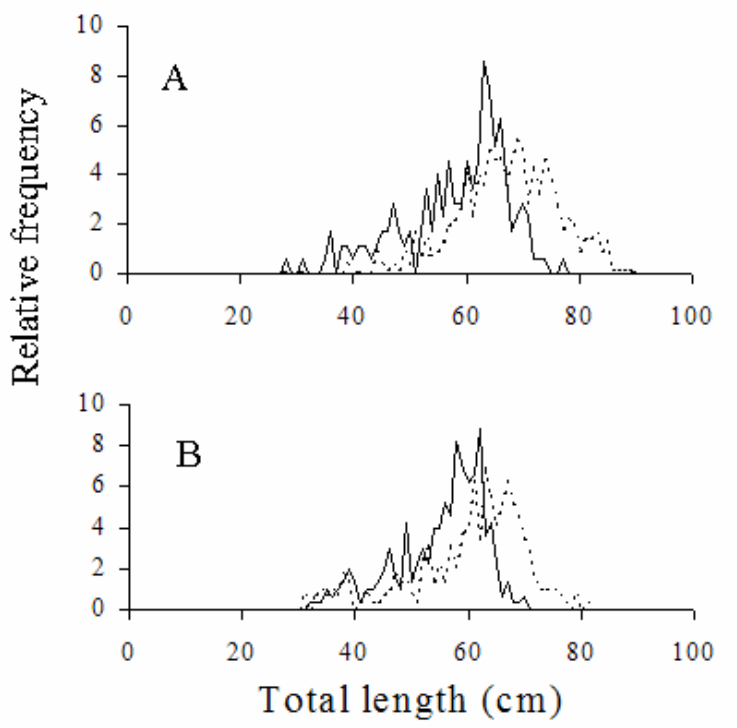

Fig. 6. Population structure Mustelus schmitti represented by the relative frequencies of total length $(\mathrm{cm})$ by sex (males $=$ solid line; females $=$ dashed line $)$ for the two groups recorded in the summer inshore cruise (A) northern group (B) southern group.
Table 2. Number (n), percentage (\%) and descriptive statistics, i.e., mean, standard deviation (SD), median and total length $(\mathrm{cm})$ range for males and females of Mustelus schmitti and number and percentage of immature (I) and mature (M) specimens by sex and group.

\begin{tabular}{|c|c|c|}
\hline & \multicolumn{2}{|c|}{ Summer 1995} \\
\hline & Northern Group & Southern Group \\
\hline $\bar{n} \delta$ & 175 & 306 \\
\hline$\%$ & 23.8 & 51.3 \\
\hline Mean ${ }^{\lambda}$ & 58.2 & 55.2 \\
\hline SD ${ }^{\lambda}$ & 9.5 & 8.0 \\
\hline Median $\partial$ & 61 & 58 \\
\hline 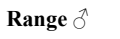 & $28-77$ & $32-70$ \\
\hline$n(\%)$ I $え$ & $37(21)$ & $76(25)$ \\
\hline$n(\%) M \curvearrowright$ & $138(79)$ & $230(75)$ \\
\hline $\boldsymbol{n}$ 우 & 560 & 291 \\
\hline$\%$ & 76.2 & 48.7 \\
\hline Mean $\phi$ & 67.2 & 60.0 \\
\hline SD ㅇ & 9.2 & 10.2 \\
\hline Median ㅇ & 68 & 63 \\
\hline Range $\circ$ & $28-90$ & $31-81$ \\
\hline$n(\%) \mathbf{I}$ 우 & 360 (64) & $264(91)$ \\
\hline $\boldsymbol{n}(\%) \mathbf{M}+$ & $200(36)$ & $27(9)$ \\
\hline
\end{tabular}

\section{Discussion}

The presence of patagonian smoothhound in most of the trawl stations showed a wide distribution of the species in the analyzed area, limited by the geographic and the operational depth range. Changes in density and total length structures for immature and mature patagonian smoothhound in the inner continental shelf (Rio de la Plata, SW Atlantic) revealed the intrapopulational structure and showed a clear migratory pattern between spring and summer in the inshore coastal area. Analyzing samples coming from offshore spring cruises, Oddone et al. (2005) observed that both males and females occurred above latitude $36^{\circ} 30^{\prime} \mathrm{S}$ only, which can be related to the migratory nature of $M$. schmitti, that moves to the warmer southern Brazilian waters in winter (Vooren, 1997). It is expected that adults be almost absent from Uruguayan waters in winter and they return to this area in spring-summer for reproduction. Both sexes occurred throughout the inshore area, which led us to conclude that M. schmitti prefers more coastal, warmer waters in spring and summer. The presence of adult females in shallow waters of up to $65 \mathrm{~m}$ in the northern area may be related to parturition and even copulation which takes place in spring or early summer in this area (Cousseau, 1986; Menni, 1985; Souto, 1986; Puig, 1987). What remains unknown is where adult females shall be situated in summer and spring. An answer could be that migration to deeper areas takes place, and that could be the reason of the low abundance when comparing with males. Such 
inshore-offshore movements were reported by Francis (1988) for Mustelus lenticulatus. Seemingly, adult females and males occur in both offshore and inshore areas in spring and summer; however, different sizes are found for a given locality and when inshore and offshore areas are compared.

Oddone et al. (2005) observed that according to the relative TL frequency in spring, juveniles of both sexes were more abundant in the offshore area, while adults occurred with the same relative frequency in both inshore and offshore areas at the same time and even in winter. Offshore autumn samples of $M$. schmitti were dominated by adult individuals (Oddone et al., op. cit.). On the other hand, In contrast to the latter, we observed that in summer and spring, juveniles occurred in inshore waters. The smallest individual reported was a $25 \mathrm{~cm}$ TL male likely a neonate- in the spring inshore cruise, and a 28 $\mathrm{cm}$ TL male in the summer inshore cruise. There was also higher incidence of individuals of less than $40 \mathrm{~cm}$ TL, which were not observed in autumn of the same year (Oddone et al., 2005).

While adult males occurred in the whole inshore and northern offshore area in spring (Oddone et al. 2005), immature females were also recorded in the inshore area in spring while adult females were restricted to the northern range of the distribution in summer, as aforementioned, in considerably less densities than males. Adult females are then situated in different areas than adult males, i.e., M. schmitti presents sexual segregation of adult stages for a given season. Sexual segregation has been largely observed in sharks (Springer, 1967, Menni et al., 1979) and was reported for M. schmitti in Argentinean waters (Menni, 1985). In some shark species, sexual segregation takes place at least during birth season and postpartum (Stevens \& McLoughlin, 1991; Ebert \& Ebert, 2005)

Seasonal migrations are common in elasmobranchs and can be driven by temperature, reproduction, foraging needs or may be food-driven (Heithaus, 2004). Similar patterns of sexual segregation reproduction-linked movements like the ones we observed for M. schmitti were observed for the sand tiger shark Carcharias taurus, occurring at different reproductive stages along Argentinean, Uruguayan and Brazilian shelves (Lucifora et al., 2002).

The split distribution of M. schmitti into two different groups observed in the summer cruise, suggests the discontinuous distribution of this species along the coast of the AUCFZ in this season. Lucifora et al. (2002) observed that female populations of $C$. taurus also split into two groups, with gravid females in the north (Brazil) and non-pregnant females, though in mating activities- in the south (Abnegada Bay, Argentina). Cousseau (1986) observed that in
Argentinean waters, there was a general trend for $M$. schmitti males to be in more coastal waters than females. In the present study, mature males occurred in both groups and mature females only above $35^{\circ} 30^{\prime} \mathrm{S}$, in the northern group. According to this fact, we hypothesize that mating takes place in the north of this area in the summer and in inshore waters. This fact is reinforced by the absence of such pattern for the spring and autumn in offshore areas (Oddone et al., 2005) and could be related to feeding activities, reproduction or abiotic factors such as temperature, salinity or currents patterns. Cousseau \& Perrota (2000) observed that M. schmitti use to form small aggregations with predominance of males or females, in our case largely dominated by the males. Lucifora $e t$ al. (2002) also observed that, similarly to M. schmitti, there was a predominance of adult males, which suggested that male competition for mates could occur.

Immature males occurred in two trawls in Samborombón Bay where there is a nursery area for this species (Cousseau \& Perrota, 2000). Other coastal nursery areas have been identified in Bahia Blanca and Bahia Engaño (Argentinean waters) (Cousseau, 1986; Van der Molen \& Caille 1998) where individuals are approximately $30 \mathrm{~cm}$ long. The fact that young $M$. schmitti were not caught has implications for the application of this survey to assess the recruitment of this species.

According to Souto (1986) copulation takes place shortly after parturition. Therefore, in this area, it may happen in summer, taking into consideration that parturition occurs in late spring and summer in the AUCFZ (Oddone et al., 2005). In the southern group, adult males and immature females coexist. Adult females could prefer the warmer water of the northern region, adjacent to southern Brazil, affected by the subtropical convergence of the Malvinas (sub-Antarctic waters) and Brazil (tropical waters) currents (Podestá et al., 1991; Guerrero et al., 1997). Parturition in late spring and summer in inshore waters coincides with higher temperatures in the coastal area, which could be favouring the growth of young-of-the-year $M$. schmitti. These individuals (between 28 and $34 \mathrm{~cm}$ TL) are caught as bycatch in the summer shrimp (Pleoticus mulleri) artisanal fisheries in La Paloma beach (Uruguay, $34^{\circ} 40^{\prime} \mathrm{S}$, $\left.54^{\circ} 09^{\prime} \mathrm{W}\right)$ (Norbis, pers. obs.).

Part of the population may not be negatively affected by fishing during springsummer (offshore waters) and summer (inshore waters) due to the seasonal ban area for the protection of young hake (Merluccius hubbsi) and stripped weakfish (Cynoscion guatucupa) (Rey et al., 1996; Ruarte et al., 2005). 
This is quite positive for Mustelus spp., since the genus is considered overfished by the IUCN list and an endangered genus by IBAMA (Vooren \& Klippel, 2005).

\section{ACKNOWLEDGEMENTS}

We are grateful to the crew of $\mathrm{R} / \mathrm{V}$ 'Aldebarán', to the colleagues of DINARA's Department of Fisheries Biology who collaborated with the sampling on board (specially to Ernesto Chiesa and Pablo Puig) and finally to the two reviewers that critically improved the submitted version of this manuscript.

\section{REFERENCES}

BAUM, J. K. et al. Collapse and conservation of shark populations in the Northwest Atlantic. Science, v. 299, n. 5605, p. 389-392, 2003.

CARRIER, J. C.; PRATT, H. L.; CASTRO, J. I. Reproductive biology of elasmobranchs. In: CARRIER, J.C., MUSICK J. A.; HEITHAUS, M. R (Ed.). Biology of sharks and their relatives. Boca Raton, Fla: CRC, 2004. p. 269-286.

COMPAGNO, L. J. V. Sharks of the world. FAO Fisheries synopsis, v. 125, 4 (1 y 2), 665 p, 1984.

COUSSEAU, B. Estudios biológicos sobre peces costeros con datos de dos campañas de investigación realizadas en 1981. VI. El gatuso (Mustelus schmitti). Fr. Mar., v. 1, n. 1, p. 60-65, 1986.

COUSSEAU, M .B.; PERROTTA, R. G. Peces marinos de Argentina: Biología, distribución, pesca. Mar del Plata: INIDEP, 2000. $167 \mathrm{p}$

EBERT, D. A.; EBERT, T. B. Reproduction, diet and habitat use of leopard sharks Triakis semifasciata (Girard), in Humboldt Bay, California, USA. Aust. J. mar Freshwat. Res., v. 56, p. 1089-1098, 2005.

EHRHARDT, N. et al. Evaluación preliminar de los recursos demersales en el Area Común de Pesca ArgentinoUruguaya 1975-1976. Instituto Nacional de Pesca, Montevideo. Infme tec., v. 13, 186 p., 1977

FIGUEIREDO, J. L. Manual de peixes marinhos do Sudeste do Brasil. Introdução: caçoes, raias e quimeras. São Paulo: Museu de Zoologia da Universidade de São Paulo, 1977. 104 p.

FRANCIS, M. P. Movement patterns of rig (Mustelus lenticulatus) tagged in southern New Zealand. NZ. J. Mar. Freshwat. Res., v. 22, p. 259-272, 1988.

GUERRERO, R. et al. Atlas hidrográfico del Río de la Plata. Buenos aires: Comisión Administradora del Río de la Plata; Montevideo: Instituto Nacional de Investigación y Desarrollo Pesquero, 1977. 109 p.

HEITHAUS, M. R. Predator-prey interactions. In: CARRIER, J. C., MUSICK, J. A.; HEITHAUS, M. R. (Ed.). Biology of sharks and their relatives. Boca Raton, Fla: CRC, 2004. p. 487-521.

LUCIFORA, L. O; MENNI, R; ESCALANTE, $\mathrm{H}$, A Reproductive ecology and abundance of the sand tiger shark, Carcharias taurus, from the southwestern Atlantic. ICES J. mar. Sci., v. 59, p. 553-561, 2002.
MENESES, P.; PAESCH, L. Características de las especies obtenidas como captura incidental en las campañas de evaluación dirigidas a merluza, corvina y pescadilla. In: ARENA, G.; REY, M. (Ed.). Estudios realizados sobre los elasmobranquios dentro del Río de la Plata y la Zona Común de Pesca Argentino Uruguaya en el marco del Plan de Investigación Pesquera INAPE-PNUD URU/92/003, p. 4-12. 1999.

MENNI, R. C. Distribución y biología de Squalus acanthias, Mustelus schmitti y Galeorhinus vitaminicus en el mar argentino en agosto-setiembre de 1978. (Chondrichthyes). Revta. Mus. La Plata (Nueva Ser.) (Secc. Zool.), v. 13, n. 138, p. 151-182, 1985.

MENNI, R. C.; LÓPEZ, H. L.; GOSZTONYI, A. E. Sobre la ecología y biología de Halaelurus bivius (Chondrichthyes, Scyliorhinidae). Revta Mus. argent. Cienc.nat. Bernardino Rivadavia Inst. nac. Invest. Cienc. nat., (Argent.) (Ecol.), v. 2, n. 3, p. 71-88, 1979.

MUSICK, J. A.; HARBIN, M. M.; COMPAGNO, L. J. V. Historical zoogeography of the Selachii. In: CARRIER, J. C., MUSICK, J. A.; HEITHAUS, M. R. (Ed.). Biology of sharks and their relatives. Boca Raton, Fla: CRC, 2004. p. 33-78.

ODDONE, M. C.; PAESCH, L.; NORBIS, W. Reproductive biology and seasonal distribution of Mustelus schmitti (Elasmobranchii, Triakidae) in the Rio de la Plata oceanic front, SW Atlantic”. J. mar. biol. Ass. U. K., v. 85, p. 1193-1198, 2005.

PODESTÁ, G.; BROWN, O.; EVANS, R. The annual cycle of satellite-derived sea surface temperature in the Southwestern Atlantic ocean. J. Clim., v.4, p. 457-467, 1991.

REY, M. et al. Areas de veda para la protección de los juveniles de merluza (Merluccius hubbsi) en la Zona Común de Pesca, hasta diciembre de 1993. Fr. Mar., v. 16, p. 7-28, 1996.

RUARTE; C., LASTA, C.; CAROZZA, C. Delimitación de un área de concentración de juveniles de pescadilla de red (Cynoscion guatucupa) en la Zona Común de Pesca Argentino-Uruguaya. Fr. Mar., v. 20, p. 51-56, 2005.

SOKAL, R. R.; ROHLF, F. J. Biometry: the principles and practice of statistics in biological research. New York: Freeman, W.H. and Company, 1998. 850 p.

SPRINGER, S. Social organization of shark populations. In: GILBERT, P. W.; MATHEWSON, R. F.; RALL, D. P. (Ed.). Sharks, skates and rays. Baltimore, Md: Johns Hopkins, 1967. p. 149-174.

STEVENS, J. D; MCLOUGHLIN, K. J. Distribution, size and sex composition, reproductive biology and diet of sharks from northern Australia. Aust. J. mar. Freshwat. Res., v. 42, p. 151-199, 1991.

STEVENS, J. D. Taxonomy and field techniques for identification: with listing of available regional guides. In: MUSICK, J. A.; BONFIL, R. (Ed.). Elasmobranch Fisheries Management Techniques. Singapore: APEC, 2004. p. 21-56.

VAN DER MOLEN, S.; CAILLE, G. Bahía Engaño: a north Patagonian nursery area for the smoothhound shark Mustelus schmitti (Carcharhiniformes: Triakidae). J. mar. biol. Ass. U.K., v. 81, p. 851-855, 2001. 
VOOREN, C. M. Demersal elasmobranchs. In: SEELIGER, U.; ODEBRECHT, C.; CASTELlO, J. P. (Ed.). Subtropical convergence environments: the coastal and sea in the Southwestern Atlantic. Berlim: SpringerVerlag, 1997. p. 141-146.

Sources of Unpublhished Material

PUIG, P. Contribución al conocimiento del gatuso Mustelus schmitti (Springer, 1940). 1987. Graduation Thesis. Facultad de Ciencias, Universidad de la República, Montevideo, Uruguay.

SOUTO, C. F. M. Estudo comparativo da reprodução nos caçoes Mustelus schmitti, Springer 1939 e M. canis Mitchill 1815 (Pisces, Squaliformes) na plataforma continental do Rio Grande do Sul-Brasil. 1986. $121 \mathrm{f}$. Dissertação (Mestrado em Oceanografia Biológica) Fundação Universidade Federal do Rio Grande, Rio Grande.

(Manuscript received 29 May 2005; revised 22 August 2006; accepted 23 March 2007) 